\title{
KARAKTERISTIK MUTU EDIBLE FILM KARAGENAN DENGAN PENAMBAHAN MINYAK ATSIRI BAWANG PUTIH (Allium sativum) PADA PRODUK PASTA IKAN
}

\author{
Khusnul Qotimah, Eko Nurcahya Dewi ${ }^{\star}$, Lukita Purnamayati \\ Program Studi Teknologi Hasil Perikanan, Fakultas Perikanan dan Ilmu Kelautan Universitas Diponegoro, \\ Jalan Prof. H. Soedarto, SH Tembalang Semarang 50275 \\ ^Korespondensi: nurdewisatsmoko@gmail.com \\ Diterima: 14 November 2019/Disetujui: 07 April 2020
}

Cara sitasi: Qotimah K, Dewi EN, Purnamayati L. 2020. Karakteristik mutu edible film karagenan dengan penambahan minyak atsiri bawang putih (Allium sativum). Jurnal Pengolahan Hasil Perikanan Indonesia. 23(1): $1-9$

\begin{abstract}
Abstrak
Edible film merupakan pengemas biodegradable yang berasal dari bahan alami, termasuk karagenan. Penelitian ini bertujuan untuk menentukan karakteristik edible film karagenan dengan penambahan minyak atsiri bawang putih (Allium sativum) konsentrasi berbeda pada produk pasta ikan. Metode penelitian yang digunakan adalah eksperimen laboratorium menggunakan Rancangan Acak Lengkap (RAL) dengan satu faktor yaitu konsentrasi minyak atsiri bawang putih $(0 \% ; 0,1 \% ; 0,3 \%$, dan $0,5 \%)(\mathrm{v} / \mathrm{v})$, masing-masing perlakuan dilakukan tiga kali ulangan. Parameter uji terdiri dari kuat tarik, persen pemanjangan, laju transmisi uap air, dan aktivitas antijamur yang diisolasi dari bakso ikan, otak-otak ikan, dan sosis ikan. Hasil penelitian menunjukkan bahwa perbedaan konsentrasi penambahan minyak atsiri bawang putih yang berbeda memberikan pengaruh nyata $(\mathrm{p}<0,05)$ terhadap kuat tarik, persen pemanjangan, laju transmisi uap air, dan aktivitas antijamur. Penambahan minyak atsiri bawang putih memberikan karakteristik dan aktivitas antijamur terbaik pada konsentrasi 0,5\%, dengan kuat tarik sebesar 14,7 MPa, persen pemanjangan 25,98\%, laju transmisi uap air 0,84 g/ $\mathrm{m}^{2} / \mathrm{jam}$, zona hambat terhadap Aspergillus niger 5,1 $\mathrm{mm}$ dan zona hambat terhadap Aspergillus flavus 4,13 mm.
\end{abstract}

Kata kunci: antijamur. bawang putih, edible film, karagenan, minyak atsiri

\section{Quality of Carrageenan Edible Film with Addition of Garlic (Allium sativum) Essential Oil}

\begin{abstract}
Edible film is biodegradable packaging which is originated from natural ingredients, including carrageenan. This study was to determine the characteristics and antifungal activities of carrageenan edible film with addition of garlic (Allium sativum) essential oil on different concentrations (0.0; $0.3 ; 0.4$; and $0.5 \%)$. The method used was laboratory experiment using a completely randomized design (CRD). Four edible films carrageenan were prepared by adding different concentrations of essential oil. The parameters tested were tensile strength, water vapor transmission rate, elongation percentage, and antifungal activity. The results showed that the different addition of garlic essential oil had significant effect $(p<0.05)$ on tensile strength, percent elongation, water vapor transmission rate, and antifungal activity. The addition of essential oil showed the best characteristics and antifungal activity was found at $0.5 \%$ concentration, with tensile strength $14.7 \mathrm{MPa}$, percent elongation $25.98 \%$, water vapor transmission rate $0.84 \mathrm{~g} / \mathrm{m}^{2} / \mathrm{hour}$, inhibition zone against Aspergillus niger $5.1 \mathrm{~mm}$ and inhibition zone to Aspergillus flavus $4.13 \mathrm{~mm}$.
\end{abstract}

Keywords: antifungal, carrageenan, edible film, essential oil, garlic 


\section{PENDAHULUAN}

Kappa karagenan diketahui dapat membentuk gel lebih baik dibandingkan iota dan lambda karagenan karena kandungan sulfatnya yang lebih rendah, sehingga potensi pemanfaatannya lebih luas, salah satunya sebagai edible film (Seol et al. 2009; Kafrani et al. 2015). Kualitas edible film tergantung pada perbandingan senyawa hidrofilik dan hidrofobik yang menyusun matriks film (Utami et al. 2017). Karagenan bersifat hidrofilik sehingga untuk pemanfaatannya sebagai edible film perlu penambahan senyawa hidrofobik, misalnya minyak atsiri.

Minyak atsiri merupakan golongan lipid yang diperoleh dari bagian tumbuhan dan bersifat volatil. Pengaplikasian secara langsung pada produk dapat menyebabkan penguapan lebih, sehingga alternatif yang dapat digunakan adalah dengan penggabungan dalam matriks film. Tujuan penggabungan dengan karagenan adalah untuk meningkatkan emulsifikasi serta dapat mengurangi transfer uap air (Aliabadi et al. 2013). Salah satu bahan yang dapat dijadikan sebagai minyak atsiri adalah bawang putih (Allium sativum).

Edible film merupakan lembaran tipis yang dapat dimakan yang dapat mencegah perpindahan massa pada bahan makanan sehingga dapat menghindari penurunan kualitas makanan. Karagenan sebagai bahan edible film mampu menghasilkan film berwarna transparan dan tidak berbau (Ituriaga et al. 2012). Di sisi lain karagenan memiliki kelemahan yaitu ketahanan yang rendah terhadap transfer uap air (Supeni 2012). Penambahan minyak atsiri bawang putih dan sorbitol dilakukan untuk mengisi ruang antar molekul dan meningkatkan kerapatan sehingga laju transmisi uap air menurun dan elastisitas meningkat (Sari et al. 2013). Amaliya dan Putri (2014) menyebutkan bahwa laju transmisi uap air yang rendah cocok digunakan untuk mengemas produk dengan kelembapan tinggi. Hal ini menunjukkan bahwa karakteristik edible film sangat penting diketahui untuk kesesuaian fungsinya sebagai pengemas produk.

Penggunaan edible film pada penelitian ini ditujukan untuk mengemas produk semi basah, karena pengemasan dengan edible film diharapkan dapat melindungi produk dari aktivitas jamur. Sebagaimana dilaporkan oleh Liu et al. (2009), bahwa kehadiran jamur berkaitan dengan aw produk, di mana produk semi basah memiliki aw 0,50-0,90 sehingga rentan terkontaminasi jamur. Berdasarkan Sung et al. (2014), minyak atsiri bawang putih dapat bersifat antijamur maupun antibakteri karena mengandung alisin/allicin. Edible film yang mengandung antijamur dapat memperpanjang masa simpan produk karena senyawa antijamur bermigrasi dan dilepaskan secara perlahan ke produk, sehingga dapat menghambat pertumbuhan jamur pada produk. Berkaitan dengan hal tersebut, pada penelitian ini, karagenan ditambahkan minyak atsiri bawang putih untuk meningkatkan kualitas edible film.

\section{BAHAN DAN METODE Bahan dan Alat}

Bahan yang digunakan dalam penelitian ini adalah karagenan yang diperoleh dari BBP4KP, Jakarta serta minyak atsiri bawang putih yang diperoleh dari Laboratorium Teknik Kimia, Universitas Diponegoro. Bakso ikan, otak-otak ikan, dan sosis ikan diperoleh dari supermarket di Semarang. Alat yang digunakan dalam penelitian ini adalah hot plate stirrer (Lab Tech, Korea), plat kaca ukuran $20 \mathrm{~cm} \times 20 \mathrm{~cm}$, oven (Memmert, Jerman), texture analyzer (Brookfield, AS), autoklaf (All American, AS), laminar air flow (Biobase, China), dan inkubator (Memmert, Jerman).

\section{Pembuatan Edible Film}

Pembuatan edible film dilakukan menurut prosedur Sousa et al. (2010) yang dimodifikasi. Sebanyak $0,8 \%(0,8 \mathrm{~g})$ sampel karagenan dilarutkan dalam $100 \mathrm{~mL}$ akuades pada gelas beker $250 \mathrm{~mL}$ dan dipanaskan pada suhu $60^{\circ} \mathrm{C}$. Selanjutnya sampel karagenan ditambahkan sorbitol $0,5 \% \quad(\mathrm{v} / \mathrm{v})$, dan dipanaskan hingga mencapai suhu $80^{\circ} \mathrm{C}$. Larutan dibiarkan pada suhu ruang selama \pm 5 menit, kemudian ditambahkan minyak atsiri dengan konsentrasi yang berbeda $(0 \% ; 0,1 \%$; $0,3 \%$, dan $0,5 \%)(\mathrm{v} / \mathrm{v})$. Larutan selanjutnya dituangkan pada plat kaca ukuran $20 \mathrm{~cm} \mathrm{x}$ $20 \mathrm{~cm}$, dan dipanaskan menggunakan oven 
pada suhu $50^{\circ} \mathrm{C}$ selama 10 jam. Edible film dilepaskan dari plat kaca dan diuji terhadap kuat tarik, persen perpanjangan, dan laju transmisi uap air. Aktivitas antijamur edible film dievaluasi dengan uji zona hambat.

\section{Aktivitas Antijamur}

Aktivitas antijamur dilakukan terhadap A. flavus dan A. niger yang diisolasi berturutturut dari bakso ikan, otak-otak ikan, dan sosis ikan. Isolasi jamur dilakukan berdasarkan prosedur Sanjaya et al. (2010). Sebanyak masing-masing satu gram sampel bakso ikan, otak-otak ikan, dan sosis ikan disuspensikan ke dalam $9 \mathrm{~mL}$ akuades steril kemudian dihomogenkan dengan vortex, sehingga diperoleh pengenceran $10^{-1}$. Selanjutnya $0,1 \mathrm{~mL}$ dari pengenceran yang telah dibuat dipipet dan ditumbuhkan pada media PDA dan diinkubasi pada suhu $25^{\circ} \mathrm{C}$. Koloni yang tumbuh diamati dan dibuat preparat mikroskopisnya untuk diidentifikasi. Aktivitas antijamur dianalisis berdasarkan metoda Utami et al. (2013). Edible film dengan diameter $5 \mathrm{~mm}$ diletakkan di atas media PDA yang telah ditumbuhkan $0,1 \mathrm{ml}$ kultur jamur A. flavus dari sampel sosis ikan dan A. niger dari sampel bakso ikan pada cawan petri. Cawan petri tersebut kemudian diinkubasi pada suhu $25^{\circ} \mathrm{C}$ selama 72 jam. Kemudian dilakukan pengukuran diameter zona hambat yang terbentuk.

\section{Uji Kuat Tarik dan Persen Pemanjangan}

Kuat tarik dan persen pemanjangan diukur berdasarkan metoda Rusli et al. (2017), menggunakan Universal Testing Machine (Texture Analyzer). Edible film dipotong dengan lebar $5 \mathrm{~mm}$ dan panjang $50 \mathrm{~mm}$. Kuat tarik $(\mathrm{MPa})$ ditentukan berdasarkan gaya maksimal (Newton) yang diberikan pada film sampai putus dibagi dengan luas film $\left(\mathrm{m}^{2}\right)$. Sedangkan persen pemanjangan (\%) dihitung dengan rumus sbb:

$\%$ pemanjangan $=\frac{\text { panjang edible film maksimum-panjang edible film awal }}{\text { panjang edible film awal }} \times 100 \%$

\section{Uji Laju Transmisi Uap Air}

Laju transmisi uap air edible film ditentukan secara gravimetri (Xu et al. 2005).
Cawan berukuran diameter $5 \mathrm{~cm}$ disiapkan, dan ke dalam cawan dimasukan $10 \mathrm{~g}$ silica gel ( $\mathrm{RH}=0 \%)$. Sampel edible film dipotong sesuai ukuran cawan dan edible film ditutupkan pada cawan tersebut. Cawan kemudian ditempatkan dalam stoples yang berisi larutan garam $\mathrm{NaCl} 40 \%(\mathrm{~b} / \mathrm{v})(\mathrm{RH}=75 \%)$ pada suhu $25^{\circ} \mathrm{C}$. Uap air yang terdifusi melalui film diserap silica gel sehingga menambah berat silica gel tersebut. Berat cawan dicatat setiap jam dan laju transmisi uap air ditentukan dengan persamaan berikut:

Laju transmisi uap air $=\frac{\text { slope } \text { kenaikan berat cawan }(\mathrm{g} / \mathrm{jam})}{\text { luas permukaan film }\left(\mathrm{m}^{2}\right)}$

\section{Analisis Data}

Penelitian ini menggunakan Rancangan Acak Lengkap dengan satu faktor yaitu konsentrasi minyak atsiri bawang putih. Masing-masing perlakuan dilakukan tiga kali ulangan. Data yang diperoleh dianalisis menggunakan sidik ragam (ANOVA). Data yang menunjukkan beda nyata kemudian dilakukan uji Tukey. Analisis data ini dilakukan dengan menggunakan perangkat lunak SPSS 23.

\section{HASIL DAN PEMBAHASAN Kuat Tarik}

Hasil pengujian kuat tarik edible film disajikan pada Figure 1. Penambahan minyak atsiri mengurangi secara signifikan nilai kuat tarik edible film. Uji Tukey menunjukkan semua perlakuan berbeda nyata. Hasil ini sesuai dengan Handayani \& Nurzanah (2018) yang menambahkan minyak atsiri lengkuas pada edible film pati talas yang menghasilkan nilai kuat tarik yang cenderung menurun seiring dengan penambahan konsentrasi minyak atsiri. Konsentrasi minyak atsiri bawang putih yang semakin meningkat menyebabkan berkurangnya interaksi antar molekul bahan penyusun edible film. Peningkatan bahan yang bersifat hidrofob akan mendorong terjadinya pembentukan ikatan hidrogen dengan molekul pati yang bersifat hidrofil, sedangkan daya tarik antar molekul pati berkurang. Hal inilah yang menyebabkan penurunan kuat tarik edible film (Sanyang et al. 2015; Rusli et al. 2017).

Murdinah et al. (2007) menyebutkan bahwa 


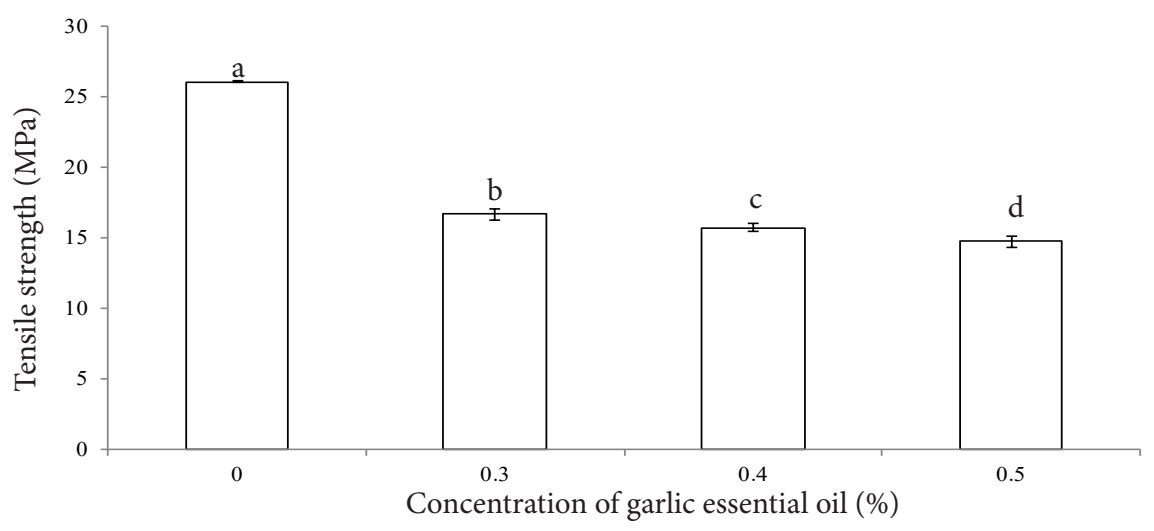

Figure 1 Tensile strength of edible film with garlic essential oil addition different letters show the significance differences $(\mathrm{P}<0.05)$

edible film harus memiliki kuat tarik tinggi agar dapat melindungi produk dari kerusakan fisik. Hasil penelitian ini menunjukkan bahwa nilai kuat tarik edible film berkisar antara 14,70 - 26,00 MPa. Hasil ini masih lebih tinggi dibandingkan dengan standar kuat tarik edible film berdasarkan Japanese Industrial Standard yaitu 3,92 MPa (Rusli et al. 2017). Hasil pada penelitian ini juga lebih tinggi dibandingkan Maizura et al. (2007), yaitu penambahan minyak atsiri dari serai pada edible film komposit tepung sagu dan alginat menghasilkan kuat tarik 12-16 MPa.

\section{Persen Pemanjangan}

Persen pemanjangan adalah penambahan panjang maksimum sebelum edible film putus akibat proses penarikan dengan gaya tertentu (Nofiandi et al. 2016). Hasil pengujian persen pemanjangan edible film disajikan pada Figure 2.
Persen pemanjangan meningkat seiring penambahan minyak atsiri, artinya terdapat pengaruh konsentrasi terhadap persen pemanjangan. Penambahan minyak atsiri pada edible film dapat meningkatkan fleksibilitas rantai polimer, sehingga persen pemanjangan meningkat. Hasil yang sama juga dilaporkan oleh Atef et al. (2015), yaitu semakin tinggi maka persen pemanjangan edible film semakin baik, karena persen pemanjangan yang tinggi mengindikasikan edible film lebih elastis dan tidak mudah sobek jika diberi beban. Persen pemanjangan pada penelitian ini adalah 14,20-25,98\% (Figure 2). Hasil pada penelitian ini lebih baik dibandingkan Praseptiangga et al. (2016), di mana penambahan minyak atsiri dari kayu manis pada edible film semi karagenan menghasilkan persen pemanjangan $4,09-6,06 \%$.

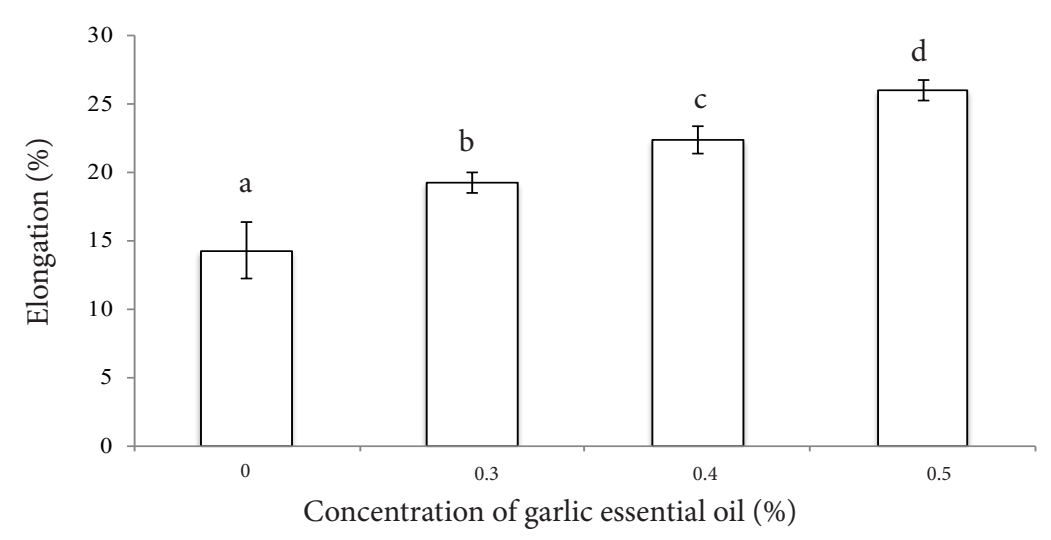

Figure 2 Elongation of edible film with garlic essential oil addition different letters show the the significance differences $(\mathrm{P}<0.05)$ 


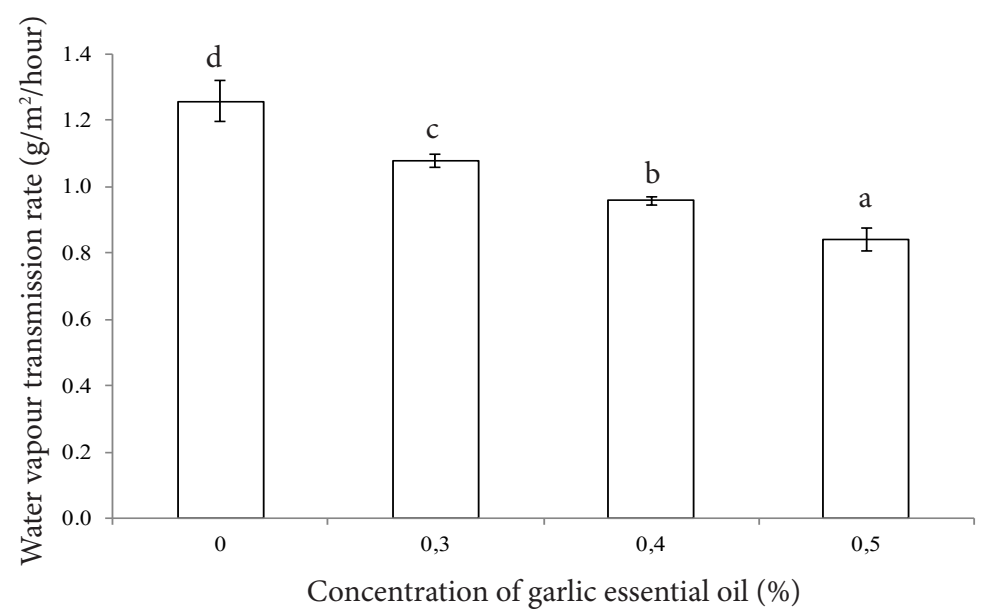

Figure 3 Water vapour transmission rate of edible film with garlic essential oil addition different letters show the significance differences $(\mathrm{P}<0.05)$

\section{Laju transmisi uap air}

Hasil pengujian laju transmisi uap air edible film disajikan pada Figure 3. Hasil penelitian ini menunjukkan korelasi negatif antara penambahan minyak atsiri dan penurunan laju transmisi uap air, artinya, laju transmisi uap air menurun seiring peningkatan konsentrasi minyak atsiri. Edible film yang baik memiliki nilai laju transmisi uap air yang rendah (Warkoyo et al. 2014). Penambahan minyak atsiri $0,5 \%$ adalah yang terbaik dalam penelitian ini.

Perpindahan uap air umumnya terjadi melalui bagian hidrofilik film dan tergantung pada perbandingan komponen hidrofilik dan hidrofobik. Penambahan minyak atsiri yang merupakan hidrofobik lipid pada polimer hidrofilik film dapat memperbaiki transfer uap air. Dengan demikian, laju transmisi uap air mengalami penurunan dengan penambahan minyak atsiri (Benavides et al. 2012).

Laju transmisi uap air pada penelitian ini 0,84-1,26\% (Figure 3), menunjukkan hasil yang lebih baik dibandingkan Aliabadi et al. (2013), dimana edible film kappa karagenan dengan penambahan minyak atsiri berupa minyak satureja menghasilkan permeabilitas uap air tertinggi sebesar $2,383 \mathrm{~g} / \mathrm{m}^{2} / \mathrm{jam}$. Menurut Amaliya dan Putri (2014), edible film dengan laju transmisi yang kecil cocok digunakan untuk mengemas produk yang mempunyai kelembapan tinggi. Edible film dapat melindungi produk dari uap air yang masuk dari lingkungan sehingga pertambahan kelembapan dapat dihambat.

\section{Aktivitas Antijamur Isolasi dan identifikasi jamur}

Produk semi basah adalah produk yang mempunyai kelembapan pada kisaran 1040\% dan aw produk 0,5-0,9 (Liu et al. 2009). Produk yang digunakan sebagai sampel dalam isolasi jamur adalah bakso ikan, otakotak ikan, dan sosis ikan. Perubahan produk selama penyimpanan pada suhu ruang dapat dilihat pada Table 1.

Berdasarkan warna jamur, dapat diketahui bahwa jamur pada otak-otak ikan dan bakso merupakan A. niger karena ditandai dengan warna hitam, sedangkan pada sosis ikan merupakan jamur $A$. flavus karena berwarna hijau. (Tyasningsih 2010).

\section{Uji zona hambat terhadap A.niger}

Hasil pengujian zona hambat edible film terhadap A. niger produk bakso ikan tersaji pada Figure 4. Semakin tinggi konsentrasi minyak atsiri bawang putih, zona hambat yang terbentuk pada produk bakso semakin besar (Figure 4). Minyak atsiri bawang putih dapat bersifat antijamur karena mengandung alisin. Menurut Nurtjahyani dan Hadra (2016), bawang putih merupakan tumbuhan yang bersifat antibakteri dan antijamur. Bawang putih mengandung alisin yang berperan penting dalam memproduksi flavor pada bawang putih (Moulia et al. 2018). Alisin tersebut merupakan salah satu senyawa aktif yang dapat merusak dinding sel jamur dan menghambat sintesis protein (Balafif et al. 2017). 
Table 1 The Changes of Intermediate Moisture Food

\begin{tabular}{llcc}
\hline \multirow{2}{*}{ Product } & \multicolumn{3}{c}{ Day } \\
\cline { 2 - 4 } & White fungus growth & More fungus, fiber appearance & The dark yellow fungus \\
\hline Fish Ball & White fungus growth & More fungus, fiber appearance & The black color of fungus
\end{tabular}

Fish Sausage White fungus growth The color of fungus changes to The dark green fungus green

Zona hambat yang dihasilkan pada penelitian ini masih tergolong lemah, yang menunjukan konsentrasi minyak atsiri yang digunakan belum mampu memberikan pengaruh yang besar terhadap aktivitas jamur target. Khasanah et al. (2017) melaporkan bahwa zona hambat termasuk sangat kuat jika zona bening yang dihasilkan $20 \mathrm{~mm}$ atau lebih, zona hambat termasuk kuat jika zona bening yang terbentuk antara $10-20 \mathrm{~mm}$, sedangkan zona hambat termasuk sedang jika daerah bening yang terbentuk antara 5-10 $\mathrm{mm}$, serta zona hambat tergolong rendah memiliki zona bening $\leq 5 \mathrm{~mm}$.

Penghambatan jamur disebabkan oleh kemampuan minyak atsiri yang bersifat antijamur (Sitepu 2012). Selain itu, aktivitas jamur juga dapat menyebabkan besarnya zona hambat yang terbentuk. Konsentrasi minyak atsiri $0,3 \%$ yang tidak menghasilkan zona hambat dikarenakan konsentrasi 0,3\% belum cukup kuat untuk menghambat aktivitas A. niger. Menurut Utami et al. (2013), faktoryang mempengaruhi ukuran daerah penghambatan, yaitu sensitivitas organisme, medium kultur, kondisi inkubasi, dan kecepatan difusi agar. Faktor-faktor yang mempengaruhi kecepatan difusi agar, yaitu konsentrasi mikroorganisme, komposisi media, suhu, dan waktu inkubasi.

\section{Uji zona hambat terhadap A.flavus}

Hasil pengujian zona hambat edible film terhadap A. flavus disajikan pada Figure 5. Semakin tinggi konsentrasi minyak atsiri bawang putih pada edible film, zona hambat yang terbentuk semakin besar (Figure 5). Zona hambat terhadap A. flavus yang dihasilkan pada penelitian ini berkisar antara 3,10 $4,13 \mathrm{~mm}$. Berdasarkan hasil yang diperoleh, dapat diketahui bahwa aktivitas antijamur minyak atsiri bawang putih terhadap $A$. flavus tergolong lemah, yaitu antara $0-4 \mathrm{~mm}$ (Dewi et al. 2019). Hasil pada penelitian ini lebih tinggi dibandingkan hasil penelitian Matan (2012), yaitu penambahan beberapa minyak atsiri (minyak cengkeh, kayu manis, kunyit, pala, adas manis, daun jambu, dan jeruk nipis) sebanyak $2 \%$ (v/v) belum mampu

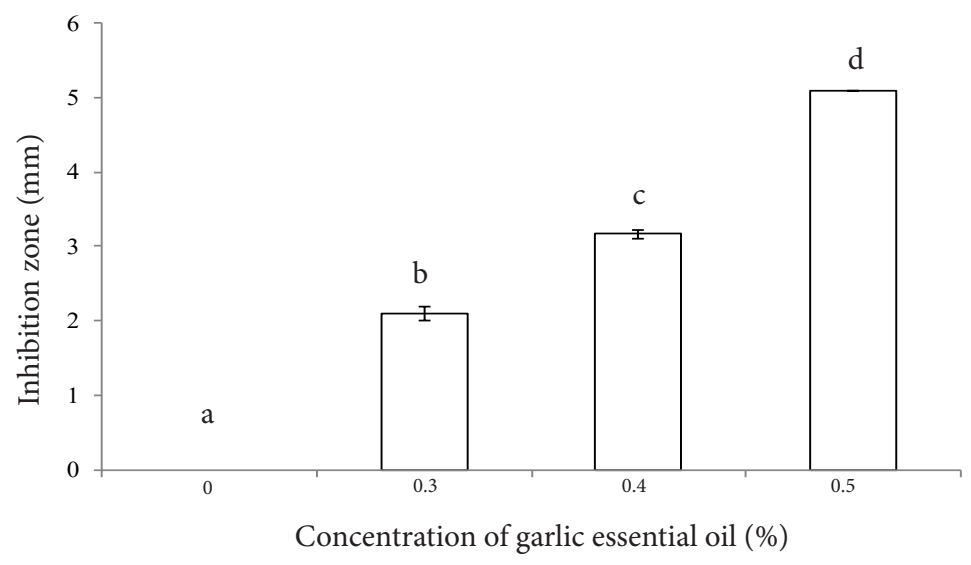

Figure 4 Inhibition Zone of Aspergillus niger different letters show the significance differences $(\mathrm{P}<0.05)$ 


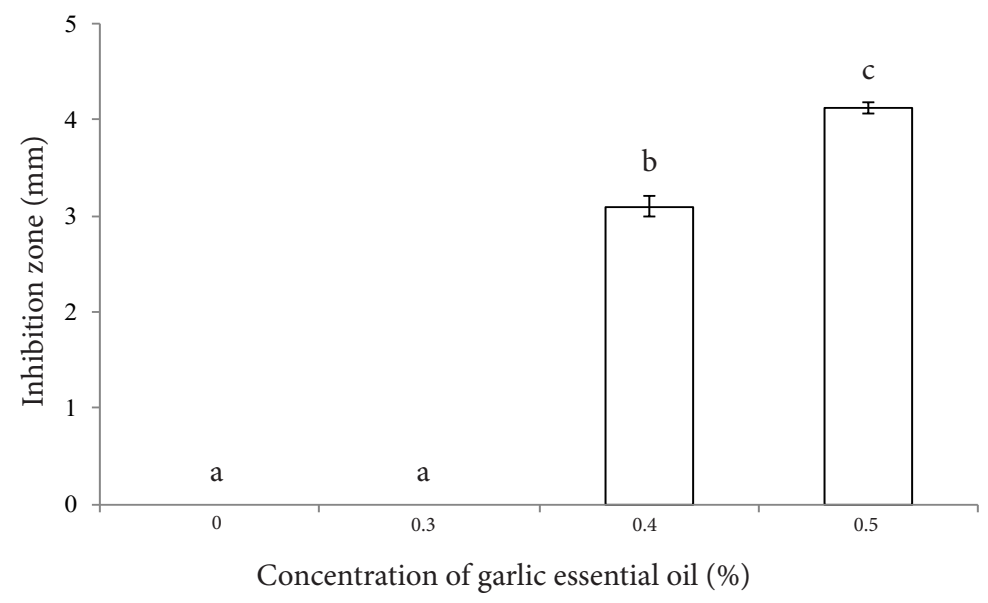

Figure 5 Inhibition Zone of Aspergillus flavus different letters show the significance differences $(\mathrm{P}<0.05)$

menghambat aktivitas jamur A. flavus dan Penicillium spp. Cara kerja dari alisin pada bawang putih dengan menyerang membran sel. Kerusakan membran sel menyebabkan aktivitas dan biosintesis enzim terhambat. Komponen utama penyusun membran sel jamur adalah sterol. Aktivitas antijamur adalah dengan menghambat biosintesis ergosterol sehingga menghambat pertumbuhan jamur. Selain itu, komponen minyak atsiri mengganggu reaksi enzimatik dari sintesis dinding sel, sehingga mempengaruhi pertumbuhan dan morfogenesis jamur (Moulia et al. 2018; Arifin et al. 2018; Jeff et al. 2012).

Penghambatan minyak atsiri bawang putih terhadap A. niger lebih tinggi daripada A. flavus. Hasil ini menunjukkan bahwa A. flavus lebih tahan terhadap minyak atsiri bawang putih dibandingkan dengan $A$. niger. Tnackov et al. (2012), menyatakan bahwa minyak atsiri memberikan efek penghambatan dengan menunda satu hari waktu germinasi $A$. niger. Berbeda halnya dengan A. flavus, karena penambahan minyak atsiri tidak menghambat pertumbuhan jamur tersebut.

\section{KESIMPULAN}

Penambahan minyak atsiri pada edible film karaginan diketahui menurunkan kuat tarik dan laju transmisi uap air, serta meningkatkan persen pemanjangan. Penambahan minyak atsiri bawang putih menghasilkan karakteristik terbaik pada konsentrasi 0,5\% yang mampu menghambat pertumbuhan
A. niger sebesar 2,1-5,1 mm dan A. flavus sebesar 3,1-4,13 mm.

\section{UCAPAN TERIMA KASIH}

Penulis mengucapkan terima kasih kepada Dekan Fakultas Perikanan dan Ilmu Kelautan Universitas Diponegoro atas terlaksananya penelitian ini melalui dana PNBP tahun 2018.

\section{DAFTAR PUSTAKA}

Arifin Z, Khotimah S, Rahmayanti S. 2018. Aktivitas antijamur ekstrak etil asetat daun mangga bacang (Mangifera foetida L.) terhadap Candida albicans secara in vitro. Jurnal Cerebellum. 4(3):1106-1119.

Aliabadi SS, Ojagh SM, Hosseini SM, Khaksar R. 2013. Characterization of antioxidantantimicrobial kappa-carrageenan films containing Satureja hortensis essential oil. International Journal of Biological Macromolecules. 52:116-124.

Amaliya RR, Putri WDR. 2014. Karakteristik edible film dari pati jagung dengan penambahan filtrat kunyit putih sebagai antibakteri. Jurnal Pangan dan Agroindustri. 2(3):43-53.

Atef M, Razaei M, Behrooz R. 2015. Characterization of physical, mechanical, and antibacterial properties of agar cellulose bionanocomposite films incorporated with savory essential oil. Food Hydrocolloids. 45:150-157.

Balafif FF, Satari MH, Dhianawaty D. 2017. Aktivitas antijamur fraksi air sarang semut Myrmecodia pendens pada 
Candida albicans ATCC 10231. Majalah Kedokteran Bandung. 49(1):28-34.

Benavides S, Carvajal RV, Reyes JE. 2012. Physical, mechanical, and antibacterial properties of alginate film: effect of crosslinking degree and oregano essential oil concentration. Journal of Food Engineering. 110:232-239.

Dewi S, Asseggaf SN, Natalia D, Mahyarudin. 2019. Efek ekstrak etanol daun kesum (Polygonum minus Huds.) sebagai antifungi terhadap Trichophyton rubrum. Jurnal Kesehatan Andalas. 8(2):198-203.

Handayani R, Nurzanah H. 2018. Karakteristik edible film pati talas dengan penambahan antimikroba dari minyak atsiri lengkuas. Jurnal Kompetensi Teknik. 10(1):1-11.

Ituriaga L, Olabarrieta I, Maranon IMD. 2012. Antimicrobial assays of natural extracts and their inhibitory effect against Listeria innocua and fish spoilage bacteria after incorporating into biopolymer Edible films. International Journal of Food Microbiology. 158:58-64.

Jeff AYA, Onifade AK, Akinyele BJ, Osho IB. 2012. In vitro antifungal activities of essential oil from nigerian medicinal plants against toxigenic Aspergillus flavus. Journal of Medicine Plants Research. 6(23):4048-4056.

Kafrani ET, Shekarchizadeh H, Behabadi MM. 2015. Development of edible films and coatings from alginates and carrageenans. Carbohydrate Polymers 2-42.

Khasanah LU, Atmaka W, Kurniasari D, Kawiji, Praseptiangga D, Utami R. 2017. Karakterisasi kemasan kertas aktif dengan penambahan oleoresin ampas destilasi sereh dapur (Cymbopogon citratus). Agritech 37(1):59-68.

Liu X, Zhou P, Tran A, Labuza TP. 2009. Effects of polyols on the stability of whey proteins in intermediate moisture food model system. Journal of Agricultural and Food Chemistry. 57:2339-2345.

Maizura M, Fazilah A, Norziah MH, Karim AA. 2007. Antibacterial activity and mechanical properties of partially hydrolyzed sago starch-alginate edible film containing lemograss oil. Journal of Food Science. 72(6):324-330.
Matan N. 2012. Antimicrobial activity of edible film incorporated with essential oil to preserve dried fish (Decapterus maruadsi). International Food Research Journal. 19(4):1733-1738.

Moulia MN, Syarief R, Iriani ES, Kusumaningrum HD, Suyatna NE. 2018. Antimikroba ekstrak bawang putih. Pangan. 27(1):55-66.

Murdinah, Darmawan M, Fransiska D. 2007. Karakteristik edible film dari komposit alginat, gluten, dan lilin lebah (Beeswax). Jurnal Pascapanen dan Bioteknologi Kelautan dan Perikanan. 2(1):19-26.

Nofiandi D, Ningsih W, Putri ASL. 2016. Pembuatan dan karakterisasi edible film dari polifenol pati sukun-polivinil alkohol dengan propilenglikol sebagai plasticizer. Jurnal Katalisator. 1(2):1-12.

Nurtjahyani SD, Hadra F. 2016. Antibacterial activity of garlic (Allium sativum) againts gram positive bacteria isolated from tiger shrimp (Penaeus monodon). Asian Pasific Journal of Tropical Disease. 6(1):46-48.

Praseptiangga D, Fatmala N, Manuhara GJ, Utami R, Khasanah LU. 2016. Preparation and preliminary characterization of semi refined kappa carrageenan based edible film incorporated with cinnamon essential oil. AIP Conference Proceedings. 1746 (1):

Rusli A, Metusalach, Salengke, Mulyati MT. 2017. Karakterisasi edible film karaginan dengan pemlastis gliserol. Jurnal Pengolahan Hasil Perikanan Indonesia. 20(2) : 219-229.

Sanjaya Y, Nurhaeni H, Halima M. 2010 Isolasi, identifikasi, dan karakterisasi jamur entomopatogen dari larva Spodoptera litura (fabricius). BionaturaJurnal Ilmu-ilmu Hayati dan Fisik. 12(3):136-141.

Sanyang ML, Sapuan SM, Jawaid M, Ishak MR, Sahari J. 2015. Effect of plasticizer type and concentration on tensile, thermal and barrier properties of biodegradable films based on sugar palm (Arenga pinnata) starch. Polymers. 7:1106-1124.

Seol KH, Lim DG, Jang A, Jo C, Lee M. 2009. Antimicrobial effect of kappacarrageenan based edible film containing 
overtransferrin in fresh chicken breast stored at $5^{\circ} \mathrm{C}$. Meat Science. 83:479-483.

Sitepu ISB, Suada IK, Susrama IGK. 2012. Uji aktivitas antimikroba beberapa ekstrak bumbu dapur terhadap pertumbuhan jamur Curvularia lunata (Wakk.) boed. dan Aspergillus flavus LINK. Jurnal Agroekoteknologi Tropika. 1(2):107-114.

Sousa AMM, Sereno AM, Hiliou L, Goncalves MP. 2010. Biodegradable agar extracted from Gracilaria vermiculophylla : film properties and application to edible coating. Materials Science Forum. 636$637: 739-744$.

Sung SY, Sin LT, Tee TT, Bee ST, Rahmat AR. 2014. Control of bacteria growth on ready to eat beef loaves by antimicrobial plastic packaging incorporated with garlic oil. Food Control. 39:214-221.

Supeni G. 2012. Pengaruh formulasi edible film dari karaginan terhadap sifat mekanik dan barrier. Jurnal Kimia Kemasan. 34(2):281-285.

Tnackov SK, Dimic G, Tanackov I, Pejin D, Mojovic L, Pejin J. 2012. The inhibitory effect of oregano extract on the growth of Aspergillus spp. and on sterigmatocystin biosynthesis. Food Science and Technology.
49:14-20.

Tyasningsih W. 2010. Potensi pakan sebagai sumber pencemaran Aspergillus spp penyebab aspergillosis pada unggas. Veterinaria Medika. 3(1):31-34.

Utami R, Nuhartadi E, Putra AYT. 2013. Pengaruh penambahan minyak atsiri kunyit putih (Kaempferia rotunda) pada edible film pati tapioka terhadap aktivitas antimikroba dan sensoris. Jurnal Teknosains Pangan. 2(2):51-56.

Utami R, Khasanah LU, Yuniter KK, Manuhara GJ. 2017. Pengaruh oleoresin daun kayu manis (Cinnamomum burmanii) dua tahap terhadap karakteristik edible film tapioka. Caraka Tani Journal of Sustainable Agriculture. 32(1):55-67.

Warkoyo, Rahardjo B, Marseno DW, Karyadi JNW. 2014. Sifat fisik, mekanik dan barrier edible film berbasis pati umbi kimpul (Xanthosoma sagittifolium) yang diinkorporasi dengan kalium sorbet. Agritech. 34(1):72-81.

$\mathrm{Xu}$ YX, Kim KM, Hanna MA, Nag D. 2005. Chitosan-starch composite film: preparation and characterization. Industrial Crops and Products. 21:185192. 